\title{
PENANGANAN AIR LIMBAH CUCIAN ALAT GELAS LABORATORIUM DENGAN METODE SPEKTROFOTOMETRI MENGGUNAKAN PEREAKSI BIRU METILEN
}

\author{
Padya Sumarwanto ${ }^{1}$, Yuni Hartati ${ }^{2}$ \\ ${ }^{1)}$ Fakultas Farmasi Universitas Gadjah Mada \\ padya_fa@ugm.ac.id \\ ${ }^{2)}$ Fakultas Biologi, Universitas Gadjah Mada \\ E-mail :
}

\begin{abstract}
ABSTRAK
Limbah cucian alat gelas laboratorium merupakan salah satu limbah yang dapat mencemari lingkungan dan berdampak buruk bagi manusia. Komponen limbah cucian alat gelas laboratorium yang paling utama adalah deterjen dengan bahan aktifnya surfaktan. Dampak lingkungan dengan adanya limbah surfaktan yang di atas ambang maksimal akan berakibat rusaknya air tanah yang akan berimbas pada kesehatan manusia. Penelitian ini bertujuan untuk mengetahui kadar surfaktan dalam air limbah cucian alat gelas laboratorium, dalam jumlah limbah 10 liter perhari. Sampel terdiri dari air limbah bilasan pertama dan air limbah bilasan kedua. Metode penelitian adalah spektrofotometri sinar tampak dengan menggunakan pereaksi biru metilen yang dilanjutkan dengan ekstraksi menggunakan kloroform. Penghitungan kadar didasarkan pada persamaan kurva baku yaitu hubungan absorbansi dari seri konsentrasi larutan standar surfaktan yang berupa dodesil benzene sulfonate $(D B S)$. Hasil pengukuran absorbansi sampel dan perhitungan konsentrasi didapat kadar DBS dari air bilasan pertama adalah $31,3449 \pm 0,2993$ ppm, sedangkan air bilasan kedua adalah 8,98645 \pm 0,775484 ppm, yang telah melebihi ambang batas maksimal yang diijinkan, yaitu 200 ug/L (Peraturan Pemerintah No. 82 Tahun 2001). Kesimpulannya penggunaan deterjen untuk mencuci alat gelas dalam laboratorium bisa diminimalkan dengan mengganti dengan mengganti larutan pencuci yang lebih ramah lingkungan.
\end{abstract}

Kata Kunci : Air limbah, alat gelas laboratorium, Surfaktan, Spektrofotometri, Biru Metilen

\section{PENDAHULUAN}

Air limbah merupakan air buangan dari masyarakat hasil sisa dari berbagai aktifitas manusia. Kandungan zat kimia dalam air limbah perlu diketahui sebagai langkah awal untuk menentukan perlakuan yang tepat terhadap air limbah tersebut. Selain itu, hal ini juga dilakukan untuk mengetahui tingkat pencemaran yang terjadi. Adanya bahan-bahan organik dalam suatu air limbah dapat mempengaruhi kehidupan dari makhluk hidup tertentu seperti ikan, serangga dan organisme lain yang sangat bergantung pada oksigen (Hindarko, 2003).

Salah satu contoh air limbah adalah deterjen. Deterjen merupakan bahan pembersih yang umum digunakan oleh usaha industri ataupun rumah tangga serta Laboratorium. Produksi deterjen terus meningkat setiap tahunnya untuk memenuhi kebutuhan masyarakat akan bahan pembersih (Connel dan Miller,1995). Deterjen merupakan gabungan dari berbagai senyawa dimana komponen utama dari gabungan tersebut adalah surface active agents atau surfaktan. Surfaktan deterjen yang paling sering digunakan adalah LAS atau Linier Alkilbenzen Sulfonat (Supriyono dkk., 1998). LAS adalah sebuah alkil aril sulfonat yang mempunyai struktur rantai lurus tanpa cabang, sebuah cincin benzen dan sebuah sulfonat. LAS merupakan konversi dari Aliklbenzen sulfonat atau ABS, dimana LAS lebih mudah terdegradasi dalam air dan merupakan deterjen 'lunak' (Hirsch, 1963 dalam Abel, 1974). Limbah deterjen merupakan salah satu pencemar yang bisa membahayakan kehidupan organisme di perairan karena menyebabkan suplai oksigen dari udara sangat lambat akibat busanya yang menutupi permukaan air (Connel dan Miller,1995).

Pengaruh deterjen terhadap lingkungan dapat diketahui dengan menganalisis kadar 
surfaktan anion atau deterjen pada sampel beberapa limbah dengan metode MBAS (Methylen Blue Active Surfactant) yakni menambahkan zat metilen biru yang akan berikatan dengan surfaktan dan dianalisis dengan spektrofotometer UV-Vis. Konsentrasi yang terbaca adalah kadar surfaktan anion pada sampel limbah yang berikatan dengan metilen biru.

\section{Air}

Menurut Peraturan Pemerintah Indonesia Nomor 82 Tahun 2001, air merupakan sumber daya alam yang memenuhi hajat hidup orang banyak sehingga perlu dilindungi agar dapat tetap bermanfaat bagi hidup dan kehidupan manusia serta makhluk hidup lainnya. Air di bumi tidak pernah terdapat dalam keadaan murni bersih, tetapi selalu ada senyawa atau mineral lain yang terlarut di dalamnya. Sebagai contoh, air hujan yang digunakan atau dimanfaatkan sebagai air aki dan air yang diambil dari mata air di pegunungan yang langsung diminum (Wardhana, 1995).

\section{Air Limbah}

Menurut Keputusan Menteri Negara Lingkungan Hidup Nomor : KEP51/MENLH/10/1995, Limbah cair adalah limbah dalam wujud cair yang dihasilkan oleh kegiatan/industri yang dibuang ke lingkungan dan diduga dapat menurunkan kualitas lingkungan baik secara langsung ataupun tidak langsung. Limbah cair terdiri dari limbah industri (industri skala besar dan skala kecil) dan limbah domestik.

Hindarko (2003) menyatakan bahwa air limbah adalah air yang tersisa setelah makhluk hidup melakukan suatu aktifitas. Air limbah selalu mengalami fluktuasi setiap hari karena berbagai aktifitas makhluk hidup, khususnya manusia.

\section{Surfaktan Anion (Deterjen)}

Surfaktan-zat aktif permukaan atau tensides- adalah zat yang menyebabkan turunnya tegangan permukaan cairan, khususnya air. Ini menyebabkan pembentukan gelembung dan pengaruh permukaan lainnya yang memungkinkan zat-zat ini bertindak sebagai zat pembersih atau penghambur dalam industri dan untuk tujuan rumah tangga (Connell, 1995).

Surfaktan atau surface active agent atau wetting agent merupakan bahan organik yang berperan sebagai bahan aktif pada deterjen, sabun dan shampoo. Surfaktan dapat menurunkan tegangan permukaan sehingga memungkinkan partikel-partikel yang menempel pada bahan-bahan yang dicuci terlepas dan mengapung atau terlarut dalam air (Effendi, 2003).

Surfaktan dikelompokkan menjadi empat, yaitu surfaktan anion, surfaktan kationik, surfaktan nonionik dan surfaktan amphoteric (zwitterionic) (Effendi, 2003).

Untuk keperluan rumah tangga digunakan kelompok surfaktan anion (deterjen). Telah dikenal dua macam deterjen anion, yakni alkil sulfonat linear dan alkil benzene sulfonat (Sastrawijaya, 1991).

Bentuk deterjen merupakan salah satu jenis bahan pembersih yang digunakan untuk mengurangi kotoran dari pakaian, piring, dan barang lainnya (Sawyer, 1967).

\section{Penentuan Surfaktan dengan Metilen Biru}

Metode ini membahas tentang perpindahan metilen biru yaitu larutan kationik dari larutan air ke dalam larutan organik yang tidak dapat campur dengan air sampai pada titik jenuh (keseimbangan). Hal ini terjadi melalui formasi (ikatan) pasangan ion antara anion dari MBAS (methylene blue active substances) dan kation dari metilen biru. Intensitas warna biru yang dihasilkan dalam fase organik merupakan ukuran dari MBAS (sebanding dengan jumlah surfaktan). Surfaktan anion adalah salah satu dari zat yang paling penting, alami dan sintetik yang menunjukkan aktifitas dari metilen biru. Metode MBAS berguna sebagai penentuan kandungan surfaktan anion dari air dan limbah, tetapi kemungkin adanya bentuk lain dari MBAS (selain interaksi antara metilen biru dan surfaktan anion) harus selalu diperhatikan. Metode ini relatif sangat sederhana dan pasti. Inti dari metode MBAS ini ada 3 secara berurutan yaitu: Ekstraksi metilen biru dengan surfaktan anion dari media larutan air ke dalam kloroform $\left(\mathrm{CHCl}_{3}\right)$ kemudian diikuti terpisahnya antara fase air dan organik dan pengukuran warna biru dalam $\mathrm{CHCl}_{3}$ dengan menggunakan alat spektrofotometri pada panjang gelombang $652 \mathrm{~nm}$ (Franson, 1992). Batas deteksi surfaktan anion menggunakan pereaksi pengomplek metilen biru sebesar $0,026 \mathrm{mg} / \mathrm{L}$, dengan rata-rata persen perolehan kembali 92,3\% (Rudi dkk., 2004). 


\section{Analisis Spektrofotometri pada Metode MBAS}

Spektrometri merupakan metode pengukuran yang didasarkan pada interaksi radiasi elektromagnetik dengan partikel, dan akibat dari interaksi tersebut menyebabkan energi diserap atau dipancarkan oleh partikel dan dihubungkan pada konsentrasi analit dalam larutan. Prinsip dasar dari spektrofotometri UV-Vis adalah ketika molekul mengabsorbsi radiasi UV atau visible dengan panjang gelombang tertentu, elektron dalam molekul akan mengalami transisi atau pengeksitasian dari tingkat energi yang lebih rendah ke tingkat energi yang lebih tinggi dan sifatnya karakteristik pada tiap senyawa. Penyerapan cahaya dari sumber radiasi oleh molekul dapat terjadi apabila energi radiasi yang dipancarkan pada atom analit besarnya tepat sama dengan perbedaan tingkat energi transisi elektronnya (Rudi, 2004).

Metilen biru digunakan untuk uji coba bahan pewarna organik. Bahan pewarna organik yang berwarna biru tua ini, akan menjadi tidak berwarna apabila oksigen pada sampel (air yang tercemar yang sedang dianalisis) telah habis dipergunakan (Mahida, 1981).

Surfaktan anion bereaksi dengan warna biru metilen membentuk pasangan ion baru yang terlarut dalam pelarut organik, intensitas warna biru yang terbentuk diukur dengan spektrofotometer dengan panjang gelombang $652 \mathrm{~nm}$. Serapan yang diukur setara dengan kadar surfaktan anion (Anonim, 2009).

\section{Tujuan Penelitian}

Penelitian ini bertujuan untuk mengetahui kadar surfaktan dalam air limbah cucian alat gelas Laboratorium. Sampel terdiri dari air limbah bilasan pertama dan air limbah bilasan kedua. Metode penelitian adalah spektrofotometri sinar tampak dengan menggunakan pereaksi biru metilen yang dilanjutkan dengan ekstraksi menggunakan kloroform. Penghitungan kadar didasarkan pada persamaan kurva baku yaitu hubungan absorbansi dari seri konsentrasi larutan standar surfaktan yang berupa dodesil benzene sulfonate (DBS) sesuai dengan Hukum Lambert-Beer seperti dalam teori spektrofotometri.

\section{Manfaat}

Penelitian ini bermanfaat untuk memberikan pengertian arti pentingnya cemaran air dalam lingkungan, sehingga pengguna 1;aboratorium bisa ikut menjaga lingkungan kita terutama air.

\section{METODE PENELITIAN \\ Bahan dan alat penelitian}

Air limbah cucian alat gelas laboratorium yaitu dari bilasan pertama dan bilasan kedua, Baku Dodesil benzene sulfonat (DBS) 10 ppm, Aquadestilata, Larutan biru metilen, Kloroform derajat pro analisis, Larutan $\mathrm{H} 2 \mathrm{SO} 4 \quad 6 \mathrm{~N}, \quad \mathrm{NaH} 2 \mathrm{PO} 4.2 \mathrm{H} 2 \mathrm{O}$, Spektrofotometer UV-Vis Spectronic 20D dari Thermo Spectronic, Kuvet visibel, Timbangan analitik, Corong pemisah, Gelas beker, Pipet ukur $2 \mathrm{Ml}$, Pipet ukur $5 \mathrm{~mL}$, Pipet Ukur $10 \mathrm{~mL}$, Gelas arloji, Kertas saring, Labu ukur $25 \mathrm{~mL}$, Labu ukur $50 \mathrm{~mL}$. Labu ukur $100 \mathrm{~mL}$, Penghisap pipet, Pipet tetes.

\section{Cara Kerja}

Pembuatan larutan pencuci

Dipipet 4,1 mL larutan $\mathrm{H} 2 \mathrm{SO} 46 \mathrm{~N}$ kemudian dimasukkan ke dalam labu ukur 100 $\mathrm{mL}$ yang berisi aquadestilata $50 \mathrm{~mL}$. Selanjutnya ditambah $5 \mathrm{~g}$ NaH2PO4.2H2O. Dikocok hingga larut sempurna, kemudian ditambahkan aquadestilata sampai tanda, dan dihomogenkan.

Pembuatan larutan seri konsentrasi baku DBS Membuat larutan baku seri konsentrasi 0,1; 0,2; 0,$3 ; 0,4$; dan $0,5 \mathrm{ppm}$ dengan cara : diambil masing-masing 0,$25 ; 0,5 ; 0,75 ; 1,0$; dan 1,25 $\mathrm{mL}$ larutan baku DBS $10 \mathrm{ppm}$. Masing-masing dimasukkan ke dalam labu ukur $25 \mathrm{~mL}$. Ditambahkan kedalamnya aquadestilata sampai tanda, kemudian dikocok sampai homogen. Larutan baku DBS dengan seri konsentrasi dimasukkan ke dalam corong pisah, ditambahkan $5 \mathrm{~mL}$ larutan biru metilen dan 10 $\mathrm{mL}$ kloroform pro analis, kemudian digojog selama 1 menit. Diamkan sebentar sampai terjadi lapisan atas dan bawah. Lapisan bawah diambil dan dimasukkan ke dalam corong pisah. Selanjutnya ditambahkan $10 \mathrm{~mL}$ larutan pencuci ke dalam corong pisah tersebut, kocok selama 1 menit, kemudian diamkan sampai terjadi dua lapisan. Lapisan yang bawah diambil dan dimasukkan ke dalam tabung reaksi. Selanjutnya diukur absorbansi mengunakan spektrofotometer. Dibuat kurva 
regresi hubungan konsentrasi dengan absorbansi.

\section{Penyiapan sampel}

Diambil 1,0 mL sampel air limbah bilasan pertama, dimasukkan ke dalam labu ukur 100 $\mathrm{mL}$, ditambahkan akuadestilata sampai tanda, dan digojog sampai homogen, sellanjutnya disebut sampel I. Selanjutnya diambil $1,0 \mathrm{~mL}$ sampel air limbah bilasan kedua (sampel II), dimasukkan ke dalam labu ukur $50 \mathrm{~mL}$ dan ditambahkan akuadestilata sampai tanda, dan digojog sampai homogen, selanjutnya disebut sampel II. Diambil $25 \mathrm{~mL}$ sampel I, dimasukkan ke dalam corong pisah, kemudian ditambahkan $5 \mathrm{~mL}$ larutan biru metilen, dan 10 $\mathrm{mL}$ kloroform pa, dikocok kuat-kuat selama 1 menit, kemudian diamkan sebentar sampai terjadi 2 lapisan. Lapisan bawah diambil dan dimasukkan ke dalam corong pisah yang lain, selanjutnya ditambah $10 \mathrm{~mL}$ dan dikocok kuatkuat selama 1 menit. Ditunggu sampai terjadi 2 lapisan, selanjutnya diambil lapisan yang bawah dan dimasukkan ke dalam tabung reaksi. Selanjutnya diukur absorbansinya menggunakan spektrofotometer.

Dilakukan perlakuan yang sama seperti sampel I terhadap sampel II.

Pengukuran absorbansi

Spektrofotometer dihidupkan powernya, diatur panjang gelombang pada 652 nm. Ditunggu 15 menit untuk kondisioning spektrofotometer. Secara berurutan larutan baku DBS dengan seri konsentrasi, larutan sampel I, larutan sampel II diukur absorbansinya menggunakan kuvet visibel. Dicatat absorbansi yang terbaca.

\section{HASIL DAN PEMBAHASAN}

Pengukuran absorbansi larutan baku dengan seri konsentrasi diperoleh data seperti pada Tabel 1 di bawah ini.

Tabel 1. Absorbansi Larutan Baku DBS

\begin{tabular}{lll}
\hline Nomor & Konsentrasi (ppm) & Absorbansi \\
\hline 1 & 0,1 & 0,101 \\
2 & 0,2 & 0,185 \\
3 & 0,3 & 0,275 \\
4 & 0,4 & 0,355 \\
5 & 0,5 & 0,436 \\
\hline
\end{tabular}

Kurva baku hubungan antara konsentrasi dengan absorbansi diperoleh seperti di bawah ini,

\section{Kurva Standar DBS}

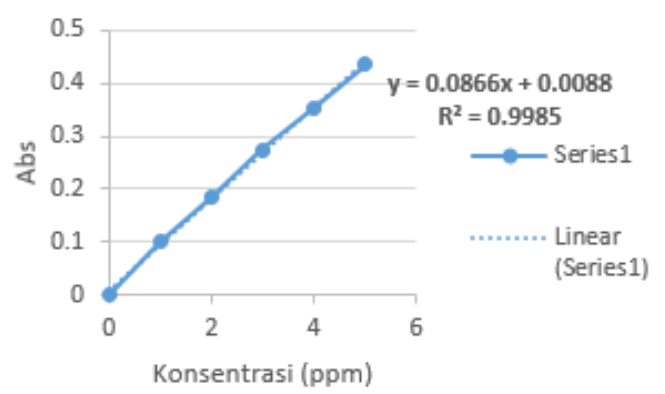

Data pengukuran absorbansi sampel I dan sampel II terdapat pada Tabel II.

Tabel II. Data Absorbansi Sampel I dan II

\begin{tabular}{lll}
\hline Nomor & Absorbansi Sampel I & Absorbansi Sampel II \\
\hline 1 & 0,278 & 0,155 \\
2 & 0,280 & 0,177 \\
3 & 0,283 & \\
\hline
\end{tabular}

Dari data absorbansi sampel yang diperoleh, didapat kadar sampel I adalah 31,3449 $\pm 0,2993$ ppm, dan sampel II adalah 8,98645 $\pm 0,775484$ ppm. 


\section{Pembahasan}

Dari data perhitungan sampel I didapat kadar surfaktan 31,3449 \pm 0,2993 ppm. Angka ini menunjukkan kandungan DBS dalam air limbah bilasan I berada di atas ambang batas maksimal yang dipersyaratkan dalam Peraturan Pemerintah No 82 Tahun 2001 yaitu 200 ug/L. Angka ini muncul dikarenakan sampel diambil langsung dari hasil cucuan alat gelas laboratorium.

Sedangkan sampel II kandungan DBS adalah 8,98645 \pm 0,775484 ppm, jauh di bawah kandungan yang terdapat pada sampel I, dikarenakan sampel yang diambil adalah air bilasan kedua setelah pencucian. Namun demikian tetap masih berada jauh di atas ambang batas maksimal diperbolehkan.

\section{KESIMPULAN}

Kandungan DBS dalam sampel I dan II jauh di atas nilai ambang batas maksimal yang diperbolehkan, sesuai dengan PP no.82 Tahun 2001, yaitu 200 ug/L.

\section{DAFTAR PUSTAKA}

Anonim, 2009, Mengetahui Dampak Air Limbah Deterjen Terhadap Organisme Air. (http://tutorjunior.blogspot.com) [18 Februari 2012]

Connel, D.W.; miller, G.J., 1995, Kimia dan Ekotoksikologi Pencemaran, UI-Press: Jakarta
Effendi, H, 2003, Telaah kualitas Air Bagi pengelolaan Sumber Daya dan Lingkungan Perairan, Jurusan MSP Fakultas Perikanan dan Ilmu Kelautan IPB, Bogor

Hindarko, S., 2003, “ Mengolah Air Limbah Supaya Tidak Mencemari Orang Lain", ESHA, Jakarta

Kristianto, P., 2002, Ekologi Industri, LPPM, Penerbit ANDI, Yogyakarta

Rudi, La, Suratno, W., dan Paundanan, J., 2004, Perbandingan Penentuan Surfaktan Anionik Dengan Spektrofotometer UVST Menggunakan Pengompleks Malasit hijau Dan Metilen biru, Jurnal Kimia Lingkungan, Vol. 6 No. 1, Surabaya: Universitas Airlangga

Sastrawijaya, A. T., 1991, "Pencemaran Lingkungan", Rineka Cipta, Jakarta

Sawyer, C. N., McCarthy, P. L., and Parkin, G. F.,1967, " Chemistry for the Environmental Engineering and Science", McGraw-Hill Company, Singapore

Supriyono, E.; Takashima, F.; Strussman, C.A., 1998, Toxicity of LAS to Juvenile Kuruma Shrimp, Penaeus japonicus : A Histopathological Study On Acute and Subchronic Levels, Journal of Tokyo University of Fisheries, Japan, Vol. 851-10 